\title{
Promise, Agreement, Contract
}

Gregory Klass

Georgetown University Law Center, gmk9@law.georgetown.edu

This paper can be downloaded free of charge from:

https://scholarship.law.georgetown.edu/facpub/2224

https://ssrn.com/abstract=3525131

Forthcoming in Research Handbook on Private Law Theories (Hanoch Dagan \& Benjamin Zipursky, eds., 2020).

This open-access article is brought to you by the Georgetown Law Library. Posted with permission of the author. Follow this and additional works at: https://scholarship.law.georgetown.edu/facpub

Part of the Contracts Commons, and the Law and Philosophy Commons 


\title{
Promise, Agreement, Contract \\ Gregory Klass ${ }^{1}$ \\ Draft: January 2020
}

To appear in Research Handbook on Private Law Theories (H. Dagan \& B. Zipursky, eds., 2020)

\begin{abstract}
It is natural to wonder about contract law's relationship to the morality of promises and agreements. This Chapter distinguishes two ways to conceive of that relationship. First, parties' agreement-based moral obligations might figure into the explanation of contract law-into an account of its functions or justifications. Contract law might serve to enforce parties' first-order performance obligations, to enforce second-order remedial obligations, to support the culture of making and keeping agreements more generally, or at least to do no harm to that culture or to people's ability to act morally. Second, contract can be understood as the legal analog to promise. Both contract and promise enable people to undertake new obligations to one another when they wish. Each is a type of normative power, the one legal, the other moral. The Chapter concludes by arguing that these two ways of thinking about contract law are not mutually exclusive. Contract law both imposes on parties to exchange agreements a legal obligation to perform for reasons independent of the parties' possible contractual intent, and confers on them the power to undertake that legal obligation when they so intend because they so intend.
\end{abstract}

\section{Introduction}

Private law concerns legal obligations persons owe one another. It is therefore natural to ask about private law's relationship to the moral sphere, which includes many similarly structured obligations. When it comes to contract law, the obvious place to look is the moral obligations that attach to promises and agreements.

This chapter examines the relationship between contract law and morality. Part One describes the conceptions of contract, promise, agreement, and voluntary obligation used in the chapter. Part Two discusses ways in which parties' moral obligations might explain their contractual ones. Part Three describes alternative accounts that do not explain contract law by way of

${ }^{1}$ Agnes N. Williams Research Professor, Professor of Law, Georgetown University Law Center. I am grateful to Hanoch Dagan, Jed Lewinsohn and Benjamin Zipursky for very helpful comments on a draft of this chapter. 
parties' moral obligations, but picture the power to contract as a legal analog to the moral power of promising. Part Four suggests a pluralist theory of contract law, which recognizes several relationships between contract law and the moral sphere.

This chapter does not address all of contract law's possible functions or justifications. Several scholars have recently emphasized, for example, contract law's role in markets, whose social and political functions extend beyond individual morality. ${ }^{2}$ Those aspects of contract law lie beyond this chapter's scope.

\section{Basic Concepts}

Contract, promise and agreement are contested concepts. One finds in the literature various conceptions of each, and a theorist's conception typically reflects her substantive commitments. This Part identifies the conceptions I employ and compares them to others one finds in the literature.

\subsection{Contracts}

This chapter employs a catholic, nondoctrinal conception of contract. A contract, as I will use the term, is a collection of legally enforceable voluntary, chosen obligations between two or more persons acting in their private capacities. ${ }^{3}$ Contractual obligations are voluntary in the sense that they are acquired by voluntary acts, such as entering into an exchange agreement or signing a formal document. They are chosen in the sense that the parties' choices determine, at least in part, the content of the obligation. ${ }^{4}$ Most tort duties are neither voluntary nor chosen. The legal obligations that traditionally attach to marriage are voluntary but not chosen. Contractual obligations are both.

The fact that contractual obligations are chosen is connected to their content independence. If $\mathrm{A}$ has a contractual obligation to $x$, it is not because the law deems A's doing $x$ worthy, but because the law deems $A$ 's choice to commit herself to $x$ ing to be a reason that $A$ should have a legal obligation to $x$. The content of the legal obligation-A's duty to $x$-is not the reason for the obligation. This does not mean that $A$ can contract for anything under the sun. $A$ contract for murder will not be enforced. Nor does it mean that social values play no role in determining the content of A's contractual obligations. Contracts

${ }^{2}$ See Roy Kreitner, Voicing the Market: Extending the Ambition of Contract Theory, 69 U. TORONTO L.J. 295 (2019).

${ }^{3}$ More precise would be to substitute in the above sentence "jural relations" for "obligations," as contracts can also generate privileges, powers, immunities and so forth. I focus on duties for the sake of simplicity.

${ }^{4}$ The choice might be made by both parties, as in a negotiated agreement or only one, as in a contract of adhesion. 
often include mandatory terms, such as minimum wages or the implied warranty of habitability. Default terms and altering rules can be crafted in light of social interests and made sticky. ${ }^{5}$ And in resolving ambiguities, a court might prefer an interpretation that is consistent with public policy. The point is simply that the act of contracting can transform a legally neutral act into a legally required one.

In Anglo-American Law one can enter into a contract in any of several ways. Most common today is the informal contract, which is generated by an exchange agreement, or an agreement "for consideration." ${ }^{6}$ To enter into an informal contract, parties must agree to a quid pro quo involving one or both's future acts or obligations. There are no formal requirements. Thus the agreement might be express or implied, and if express, oral or written.

In jurisdictions that still recognize the seal, one can also enter into a contract by undertaking a commitment in a signed and sealed writing delivered to the obligee. Unlike informal contracts, these formal contracts require neither consideration nor acceptance. ${ }^{7}$ Compliance with the formal requirements suffices.

The catholic conception of contract also captures duties generated by the doctrine of promissory estoppel, which provides that a person acquires a legal obligation by making a commitment on which the promisee foreseeably and detrimentally relies, if nonenforcement of the commitment would be unjust. ${ }^{8}$ Promissory estoppel is today commonly thought of as an alternative to liability in contract. But when Williston introduced the idea, he treated reliance as a substitute for consideration, resulting in a contract like any other. ${ }^{9}$ And coming from a very different perspective, Grant Gilmore argued that promissory

${ }^{5}$ See lan Ayres \& Robert Gertner, Majoritarian vs. Minoritarian Defaults, 51 STAN. L. REV. 1591, 1598-1600 (1999); Eyal Zamir, The Inverted Hierarchy of Contract Interpretation and Supplementation, 97 COLUM. L. REV. 1710, 1738-53, 1755-58 (1997). Because impeding altering rules can provide gradations of stickiness, there is in fact a range of possibilities between chosen and nonchosen obligations. See lan Ayres, Regulating Opt-Out: An Economic Theory of Altering Rules, 121 YALE L.J. 2032, 2084-2113 (2012). Fiduciary obligations, for example, lie somewhere between entirely chosen and entirely mandatory. See Gregory Klass, What If Fiduciary Obligations Are Like Contractual Ones?, in CONTRACT, Status, AND FiduCIARY LAW 93 (Paul B. Miller \& Andrew S. Gold, eds., Oxford Univ. Press 2017).

${ }^{6}$ The exchange conception of consideration is today the dominant one. For an argument for an alternative, see Jed Lewinsohn, Paid on Both Sides: Quid Pro Quo Exchange and the Doctrine of Consideration, 129 YALE L.J. (forthcoming 2020).

7 See Restatement (SECOND) OF ContRAct §§ 95, 104 (1981).

${ }^{8}$ See RESTATEMENT (SECOND) OF CONTRACT § 90(1) (1981).

${ }^{9}$ See Samuel Williston, 2 THE LAW OF CONTRACTS § 139, at 307-14 (1920)

("Estoppel as a substitute for consideration."). 
estoppel "has, in effect, swallowed up the bargain principle." ${ }^{10}$ The catholic conception of contract is designed to accommodate such claims.

Common law jurisdictions differ on whether the existence of an informal contract depends on the parties' intent to be legally bound. ${ }^{11}$ The black-letter law in England and elsewhere in the Commonwealth requires that parties intend to contract. "For a contract to come into existence, there must be ... an intention to create legal relations." 12 In the United States, the Second Restatement states that "[n]either real nor apparent intention that a promise be legally binding is essential to the formation of a contract, but a manifestation of intention that a promise shall not affect legal relations may prevent the formation of a contract."13 The American rule admits of exceptions. A U.S. court might look to the parties' intent to contract in cases involving, for example, preliminary agreements, interfamily agreements, and reporters' promises of confidentiality.

It is an interesting question whether this difference in black-letter rules makes a difference in practice. Several scholars have argued that courts apply the English rule as cover for policy judgments. When the court finds enforcement of the agreement unproblematic, it does not inquire into the parties' contractual intent; when it wishes to deny enforcement, it finds the parties contractual intent lacking. ${ }^{14}$ Others have argued that in the United States, the consideration requirement serves as a proxy test for the parties' intent to contract, so U.S. law too is designed to sort for a contractual intent. ${ }^{15}$ As is not uncommon, scholars' interpretations of the rule and its application often correlate with their broader views on contract law's function and justification. The above conception of contract accommodates both the American and English rules for contractual intent.

${ }^{10}$ Grant Gilmore, The DeATH OF CONTRACt 72 (Columbus: Ohio State U. Press 1974).

${ }^{11}$ See Gregory Klass, Intent to Contract, 1437 VA. L. ReV. 1437, 1443-53, 1475-79 (2009).

${ }^{12}$ Baird Textile Holdings Ltd. v. Marks \& Spencer plc [2001] EWCA (Civ) 274, [59] (Eng.).

${ }^{13}$ Restatement (SECOND) OF CONTRACT § 21 (1981).

${ }^{14}$ See P.S. Atiyah, AN INTRODUCTION TO THE LAW OF CONTRACT 153 (5th ed. 1995) (arguing that the English rule's presumption of intent to contract means that in most cases it is "more realistic to say that no positive intention to enter into legal relations needs to be shown."); Stephen Hedley, Keeping Contract in Its Place-Balfour v. Balfour and the Enforceability of Informal Agreements, 5 Oxford J. Legal Stud. 391 (1985); Mary Keyes \& Kylie Burns, Contract and the Family: Whither Intention?, 26 MELB. U. L. REV. 577 (2002).

${ }^{15}$ Lon L. Fuller, Consideration and Form, 41 ColuM. L. REV. 799, 801 (1941); Randy E. Barnett, A Consent Theory of Contract, 86 ColuM. L. Rev. 269, 313 (1986). 
The relevance vel non of the parties' legal intent is clearer when it comes to formal contracts and promissory estoppel. Employing a formality like the seal is just an expression of the sealer's intent that the document be legally effective. The rules for formal contracts therefore sort for parties' contractual intent. The doctrine of promissory estoppel, in distinction, with its emphasis on reliance and the demands of justice, appears not to require that the promisor intend to acquire a legal commitment. ${ }^{16}$ Thus in Cohen v. Cowles Media, the Minnesota Supreme Court could hold both that a reporters' confidentiality promise did not create a contract because it was not made with an intent to be legally bound, and that the source might nonetheless bring a claim of promissory estoppel. ${ }^{17}$

\subsection{Promises}

This chapter employs a relatively narrow conception of promises: a promise to $x$ is the expression of an intention to acquire a moral obligation to $x$ by that very expression. ${ }^{18}$ This definition does not address several important theoretical questions, such as whether a successful promisor must actually intend to acquire a promissory obligation (one can express an intention without having it) or whether one can promise by accident (one can express something unintentionally). Nor does it take a position on whether promissory obligations

${ }^{16}$ It is difficult to say anything substantive about promissory estoppel without someone pushing back against it. Compare Randy E. Barnett \& Mary E. Becker, Beyond Reliance: Promissory Estoppel, Contract Formalities, and Misrepresentations, 15 HofSTRA L. Rev. 443, 496 (1987) ("In most cases in which liability is imposed only on the basis of promissory estoppel, liability can be understood as contractual in the broad sense that the promisor apparently intended to assume a legal obligation under an objective standard."), with Michael B. Metzger \& Michael J. Phillips, Promissory Estoppel and Reliance on Illusory Promises, 44 SW. L.J. 841, 901 (1990) ("[T]he argument that promissory estoppel is consensual fails because it ignores the express basis on which innumerable promissory estoppel decisions have proceeded, and because the consent-based theory of promissory liability it presupposes cannot account for the courts' tendency to enforce illusory promises.").

${ }^{17} 457$ N.W.2d 199 (Minn. 1990), reversed on other grounds, 501 U.S. 663 (1991). But see Garwood Packaging, Inc. v. Allen \& Co., 378 F.3d 698, 705 (7th Cir. 2004) (Posner, J.) ("[T]he essence of the doctrine of promissory estoppel is not that the plaintiff have reasonably relied on the defendant's promise, but that he have reasonably relied on its being a promise in the sense of a legal commitment, and not a mere prediction or aspiration or bit of puffery.").

${ }^{18}$ See, e.g., Joseph Raz, PROMISES AND Obligations, In LAW, MORALITY, AND SOCIETY: ESSAYS IN HONOUR Of H.L.A. HART 210, 218 (P.M.S. Hacker \& J. Raz eds., 1977) ("To promise is ... to communicate an intention to undertake by the very act of communication an obligation to perform a certain action."). 
presuppose a social convention of promising. ${ }^{19}$ On the above conception, not all promises involve the use of the words "I promise." But a promise can always be translated into a sentence of the form, "I promise to $x$." Successful promises in this sense are the exercise of a moral normative power: The expression of an intention to effect a normative change suffices to do so.

Some theorists employ broader conceptions of promising. Seana Shiffrin, for example, uses "promise" to refer generally to the voluntary commitments we make to others, though she allows that there might be differences in strength between express promises and others. ${ }^{20}$ Thomas Scanlon suggests that a promise to $x$ is, roughly, the expression of a firm intention to $x$, where the promisee seeks such assurance and the promisor intends to provide it. ${ }^{21} \mathrm{~A}$ theorist's conception of what a promise is often tracks her substantive commitments about why promises are binding. Thus, some theorists might deny that a promise in the above narrow sense, without more, generates a moral obligation.

There are a few more things to say about about promises. To be binding, the promisee must accept, or at least not reject, it. ${ }^{22}$ And a completed promise gives the promisee a new normative power: the power to release the promisor from her obligation. ${ }^{23}$ Promises therefore involve three normative

${ }^{19}$ See, e.g., Niko Kolodny \& R.J. Wallace, Promises and Practices Revisited, 31 PHIL. \& PUB. AfF. 119 (2003).

20 " $[\mathrm{A}]$ promise is a voluntary commitment to perform (or to omit) an action that the promisor has the authority to perform, a commitment qualified (sometimes explicitly) by apt conditions of performance, that works by transferring some form of the promisor's right to decide whether or not to perform that action to the promisee." Seana Vallentine Shiffrin, Is a Contract a Promise?, in THE ROUTLEdGe COMPANION TO PHILOSOPHY of LAW 241, 243-44 (Andrei Marmor ed., 2012). See also James Penner, Promises, Agreements, and Contracts, in PHILOSOPHICAL FOUNDATIONS OF CONTRACT LAW 116, 117-18 (G. Klass, et al. eds., Oxford Univ. Press 2014) (defining "promise" as "a voluntarily undertaken obligation which is unilateral in character").

${ }^{21}$ Thomas Scanlon, Promises and Practices, 19 PHIL. \& PUblic AfF. 199, 207 (1990); T.M. Scanlon, Promises and Contracts, in THE THEORY OF CONTRACT: NEW ESSAYS 86, 103 (P. Benson ed., 2001). See also Neil MacCormick, Voluntary Obligations and Normative Powers-l, 46 Proc. ARISTOTELIAN SOC'Y 59, 62 (Supp. 1972) (describing a promise as "an utterance of the speaker's about his own future conduct which is essentially characterized by the speaker's intending his addressee to take it as being intended to induce the addressee to rely upon the speaker's taking the action in question"); P.S. Atiyah, PROMISES, MORALS, AND LAW 184 (1981) (describing a promise as an admission of the existence of prior obligations that "can arise without any intention of assuming an obligation, without any consent or express promise").

${ }^{22}$ David Owens, Shaping THE NoRMative LANDSCAPE 146 (2012).

${ }^{23} / d$. 
powers: the promisor's power to promise, the promisee's power to accept or to reject, and the promisee's power to release. Finally, like contracts, the obligation generated by the promise is content-independent. If a promise to $x$ creates a moral obligation to $x$, it is not because doing $x$ is morally worthy, but because of the promise to $x$. A promise can transform a morally neutral act into a morally required one. It is this last feature of promises that Hume characterized as "one of the most mysterious and incomprehensible operations that can possibly be imagined, [which] may even be compared to transubstantiation, or holy orders, where a certain form of words, along with a certain intention, changes entirely the nature of an external object, and even of a human nature." 24

\subsection{Agreements}

A practical agreement is an agreement that one or both parties shall do something, as distinguished, say, from an agreement that something is the case. Not all practical agreements involve promises in the above sense. If I agree with my friend Christian to read and discuss Michael Tomasello's new book together, I have not necessarily promised to do so. I have not declared my intention to be obligated by the very declaration of that intention. We know this is so because if Christian doubts whether I will follow through, he might ask, "Do you promise?" J.L. Austin compares the difference between nonpromissory agreements and promises to that between saying "S is $\mathrm{P}$ " and saying "I know $S$ is P." "But now, when I say 'I promise', a new plunge is taken; I have not merely announced my intention, but, by using this formula (performing the ritual), I have bound myself to others, and stake my reputation, in a new way." ${ }^{25}$

What are the defining characteristics of nonpromissory practical agreements? This turns out to be a difficult question. Here it is enough to observe that such agreements always involve shared intentions: each party has an intention about what each shall do; those intentions interlock or mesh with one another; and they refer to one another. ${ }^{26}$ Shared intentions also involve a degree of mutual reliance. At a minimum, each person builds the other's intentions and probable performance into her own practical reasoning. ${ }^{27}$ Shared intentions do not, however, require promises. As Margaret Gilbert observes,

${ }^{24}$ David Hume, A Treatise On Human NatURe 524 (L.A. Selby-Bigge ed., Oxford Univ. Press 1978) (1739-1740) (emphasis in original; footnote omitted).

25 J.L. Austin, Other Minds, in PHILOSOPHICAL PAPERS 76, 99 (3d ed., 1979).

${ }^{26}$ The above is an abbreviated and incomplete description of Michael Bratman's analysis of shared intentions. See Michael E. Bratman, Shared Intention, 104 ETHICS 97 (1993). See also Margaret Gilbert, What Is It for Us to Intend?, in SOCIALITY AND RESPONSIBILITY 14 (Lanham: Rowman \& Littlefield 2002).

${ }^{27}$ Facundo M. Alonso, Shared Intention, Reliance, and Interpersonal Obligations, 119 ETHICS 444 (2009); Facundo M. Alonso, What is Reliance?, 44 CANADIAN J.

PHIL. 163 (2014). 
two people "need not, in fact, mutually express willingness to be jointly committed to intend to do $A$ as a body in order to be so committed." 28

Although one can enter into a nonpromissory agreement to $x$ without declaring one's intention to acquire a moral obligation to $x$, one might nevertheless thereby acquire such an obligation. If I defect from my agreement with Christian to read and discuss the book with him, I might wrong him, even if I never promised to read. That obligation might derive from any number of facts: Christian's reliance on the agreement, the fact that by agreeing I have invited him to trust me, a duty of reciprocity, the value of our friendship, or something else. ${ }^{29}$ The moral duty to perform a nonpromissory agreement cannot arise, however, by virtue of a declaration of an intention to undertake the obligation. There has been no such declaration.

Nonpromissory agreement-based moral obligations are in several ways similar to promissory obligations. The obligations are both voluntary and chosen. They are content independent: it is the parties' agreement to $x$, as distinguished from the moral value of $x$ ing, that generates the obligation. Just as a promise must be accepted, an agreement is the work of at least two persons and can therefore be generated by an offer followed by its acceptance. And each side has the power to release the other from the agreement.

\subsection{Voluntary Obligations}

Contracts, promises and agreements all generate voluntary obligations. David Owens distinguishes three senses in which an obligation can be said to be voluntary. ${ }^{30}$ An obligation is first grade voluntary if a person's practical decision-her decision to do something-is part of how she acquired the obligation, whether or not she knew or intended her act to have that effect. An obligation is second grade voluntary if a person's practical decision put her under the obligation only because she made it with the knowledge that it would have that effect. An obligation is third grade voluntary if it arose by virtue of the obligor's expression of an intention to, by that expression, acquire the obligation. A third-grade voluntary obligation results from the exercise of a normative power. It "is an obligation you undertake rather than incur." ${ }^{31}$

Promissory obligations as I have defined them are always third grade voluntary. They are exercises of a moral normative power. A nonpromissory agreement-based obligation, in distinction, might be either first or second grade voluntary. An agreement-based duty always results from a person's voluntary

${ }^{28}$ Gilbert, supra note 26, at 24. See also Margaret Gilbert, Is an Agreement an Exchange of Promises?, 90 J. PHIL. 628 (1993).

${ }^{29}$ See Gregory Klass, Promise Etc., 45 Suffolk U. L. ReV. 695, 701-04 (2012) (discussing nonpromissory agreement-based obligations).

${ }^{30}$ Owens, supra note 22 , at 3-6. Owens uses the term "choice dependent" rather than "voluntary."

${ }^{31}$ Id. at 127. 
act-entering into an agreement-and sometimes also the obligor's knowledge that she is acquiring it.

Under the American rule, a contractual obligation might be first, second or third grade voluntary. If the legal obligation attaches because the parties have expressed an intent to be legally bound, it is third grade voluntary. This describes, for example, formal contracts. If, on the contrary, the law makes room for entry into contracts by accident-say by agreeing to an exchange unaware of the legal consequences - the resulting legal obligations are only first grade voluntary. The Second Restatement, for example, suggests that two parties might orally agree to the sale of a book under the mistaken belief that their agreement is not enforceable because it is not in writing, yet find themselves in a contract. ${ }^{32}$ Finally, one can imagine a rule that conditions contractual liability on the parties' apparent knowledge that they are entering into a legally binding agreement, without requiring that they express an intent to do so. The resulting contractual obligations would be second grade voluntary.

Here a caveat is perhaps in order. Owens's categorization of voluntary obligations turns on the reasons the obligation exists. It might be, for example, that the vast majority of parties entering into exchange agreements expect the legal obligations that attach to them. That fact would not entail, however, that those expectations are part of the law's reason for attaching the obligations. Most adults in the United States know that by earning an income they are likely to incur an obligation to pay employment taxes. That knowledge does not, however, figure into the law's reasons for imposing those taxes. The same goes for contract law. Even if, as a matter of fact, most parties to exchange agreements expect or intend the legal obligations associated with them, we need a further argument those expectations or intentions figure into the law's reasons for assigning parties those legal obligations.

\section{Moral Obligations as Explanations for Contract Law}

Having described contracts, promises and nonpromissory agreements, I now turn to the relationships between them. This Part identifies several ways in which parties' moral obligations might figure into the explanations of their contractual obligations-ways parties' moral obligations might figure into the law's reasons for assigning them contractual obligations. These are ways in which contract law's purpose or justification might be connected to the moral sphere. The next Part discusses theories that do not explain contract law by way of the parties' moral obligations, but suggest that contracts are in an important way similar to promises narrowly understood.

A moral explanatory theory of contract must answer two questions. What are contracting parties' moral obligations to one another? And how do those obligations explain the parties' legal obligations?

${ }^{32}$ Second Restatement $\S 21$ ill. 2. 


\subsection{Parties' Moral Obligations}

The Second Restatement defines "contract" as "a promise or a set of promises for the breach of which the law gives a remedy, or the performance of which the law in some way recognizes as a duty." 33 But its definition of "promise" is closer to what I am calling "agreement." "A promise is a manifestation of intention to act or refrain from acting in a specified way, so made as to justify a promisee in understanding that a commitment has been made. ${ }^{134}$ Nor do the conditions of contractual validity-the rules that determine when a contract comes into existence-require that parties promise performance. Section 4 of the Second Restatement provides that a "promise may be stated in words either oral or written, or maybe inferred wholly or partly from conduct." 35 The comments give the following illustration: "A telephones to his grocer, 'Send me a ten-pound bag of flour.' The grocer sends it. A has thereby promised to pay the grocer's current price therefor." ${ }^{36}$ In context, A has agreed to pay for the flour. But it is not obvious that $A$ has expressed his intention to undertake an obligation (moral or legal) by the very expression of that intention. If $A$ had failed to pay for groceries in the past, it would be perfectly intelligible for the grocer to reply, "Do you promise to pay for it?" The same goes for many express contracts, in which the parties explicitly agree to an exchange without promising to perform. Thus the Uniform Commercial Code can eschew talk of promises altogether. It defines "contract" as "the total legal obligation that results from the parties' agreement." ${ }^{\prime 37}$

One might object that the point is merely semantic. I have adopted a narrow conception of promising. If one uses "promise" to refer to the acquisition of voluntary obligations generally, as Shiffrin and others do, ${ }^{38}$ one might say that contracts involve promises. But the distinction is an important one.

First, some theorists have identified contract with promise in the narrow sense. Charles Fried, for example, suggests that "[a]n individual is morally bound to keep his promises because he has intentionally invoked a convention whose function it is to give grounds-moral grounds-for another to expect the promised performance." ${ }^{39}$ This looks very much like the narrow conception of promises, which fits with Fried's emphasis on autonomy and

${ }^{33}$ Restatement (SECOND) OF CONTRACTS $§ 1$ (1981).

${ }^{34}$ Id. $\S 2$.

${ }^{35}$ Id. $\S 4$.

${ }^{36}$ Id. ill. 1.

${ }^{37}$ U.C.C. § 1-201(12).

${ }^{38}$ See supra note 20.

${ }^{39}$ Charles Fried, Contract As Promise: A Theory of Contractual Obligation 16 (1981). See also, id. at 57 ("The moral force behind contract as promise is autonomy: the parties are bound to their contract because they have chosen to be."). 
freedom of contract. But then one might doubt the premise of his central claim: that "since a contract is first of all a promise, the contract must be kept because a promise must be kept." 40 Many contracts do not involve promises in the sense Fried uses the term. ${ }^{41}$

Second, recognizing that contracts more often involve agreements than promises per se answers a possible objection to moral accounts of contract law. Michael Pratt has observed that one might enter into a contract while effectively disclaiming a promise to perform. ${ }^{42}$ This fact is fairly unsurprising. Because a promise is just an expression of an intent to undertake an obligation by the very expression of that intent, promissory obligations can always be avoided in this way. It is not obvious, however, that one can so avoid nonpromissory agreement-based moral obligations. Such obligations might be more like those that attach to friendship, which cannot be forestalled by simple disclaimer. (It would be extremely odd to say to someone, "Although I consider you a friend, I hereby disclaim any moral obligations of amity toward you.") The same might go for the nonpromissory moral obligations that attach to contractual agreements. ${ }^{43}$

Third, several scholars have sought to reconcile economic analyses of contract law with promissory theories by emphasizing promisors' control over their obligations. ${ }^{44}$ The argument is that a promisor has the power to specify not only the content of her first-order moral obligation to perform, but also what she will owe the promisee if she fails to perform. This radical malleability of promissory obligations, these theorists argue, renders economic arguments for the expectation remedy, including the theory of efficient breach, compatible with promissory theories of contract. If economic analysis shows that

${ }^{40} / d$. at 17.

${ }^{41}$ P.S. Atiyah makes something like this point in his review of Contract as Promise. "The promises of the parties are legal constructs that cannot be identified until we have decided what the parties ought to do. Obligation comes first, promise afterwards." P.S. Atiyah, Book Review, 95 HARV. L. ReV. 509, 519 (1981) (reviewing Charles Fried, CONTRACT AS PROMISE: A THEORY OF CONTRACTUAL OBLIGATION (1981)).

${ }^{42}$ Michael G. Pratt, Contract: Not Promise, 35 FlA. ST. L. ReV. 801 (2008).

${ }^{43}$ This is, in essence, Shiffrin's response to Pratt, though Shiffrin uses "promise" in a broader sense than I do. See Shiffrin, supra note 20, at 245-48.

${ }^{44}$ Richard Craswell, Contract Law, Default Rules, and the Philosophy of Promising, 88 MICH. L. REV. 489 (1989); Jody S. Kraus, The Correspondence of Contract and Promise, 109 Colum. L. REv. 1603 (2009); Daniel Markovits \& Alan Schwartz, The Myth of Efficiency Breach: New Defenses of the Expectation Interest, 97 VA. L. REV. 1939 (2011). The above skips over important differences in nuance, but I believe gets at a common mode of argument. For more detailed assessments of Markovits and Schwartz's version, see Seana Valentine Shiffrin, Must I Mean What You Think I Should Have Said?, 98 VA. L. REV. 159 (2012); Gregory Klass, To Perform or Pay Damages, 98 VA. L. ReV. 143 (2012). 
sophisticated promisors prefer remedies that allow for efficient breach, the expectation measure can be understood "as the law's best guess about the remedial moral duty that most promisors would prefer." ${ }^{45}$

I have my doubts about whether promissory obligations are so malleable. Joseph Raz, for example, has argued that though promisors have the ability to limit the circumstances that excuse their performance, they do not have the ability to affect the strength of the reason to perform. ${ }^{46}$

Be that as it may, the above reconciliation strategy is much less plausible when applied to nonpromissory agreement-based obligations. Just as it is not obvious that nonpromissory agreement-based obligations can be avoided by simple disclaimer, it is not obvious that one who incurs such an obligation has the power to affect its strength or the remedial obligations that attach to its breach. Jody Kraus has argued that "[i]f personal sovereignty explains and justifies promissory obligations on the ground that they vindicate the will of the individuals who incur them, then the remedial moral duties, if any, that attach to the violation of those obligations should also be subject to the will of the individuals who create the obligations." ${ }^{47}$ It is not obvious that such autonomy-based arguments apply pari passu to nonpromissory agreement-based obligations, which are only first or second grade voluntary.

Finally, and more generally: In our everyday moral reasoning, we often attach a special weight or significance to promissory obligations. To ask for a promise is to ask for an extra assurance. To promise is to render nonperformance more wrongful than it otherwise would be. In thinking about the possible relationship between parties moral and contractual obligations, the source and character of their moral obligations matter.

\subsection{Moral Explanatory Theories}

If parties' contractual obligations are explained, in part or in full, by their moral obligations, then those moral obligations stem from agreements to perform that might or might not involve promises. I have not yet argued that parties always have a moral obligation to perform. Does a consumer who is legally bound to click-wrap adhesive terms, which it would have been irrational for her to read and which she predictably ignored, have a moral obligation to abide by those terms? ${ }^{48}$ If a residential mortgage is securitized and then purchased by an institutional investor in a bet on the housing market, does the homeowner have a moral obligation to pay it back, even if it is in the

\footnotetext{
${ }^{45}$ Kraus, supra note 44, at 1635.

${ }^{46}$ Joseph Raz, Is There a Reason to Keep a Promise?, in PHILOSOPHICAL FOUNDATIONS OF CONTRACT LAW 58, 64-65 (G. Klass et al. eds., Oxford Univ. Press 2014).

${ }^{47}$ Kraus, supra note 44 , at $1629-30$.

${ }^{48}$ See Tess Wilkinson-Ryan, A Psychological Account of Consent to Fine Print, 99 IOWA L. REV. 1745 (2014).
} 
homeowner's financial interest to default? ${ }^{49}$ What about an agreement between two corporations, each of whose officers understand her and her counterpart's primary duty to be to maximize shareholder returns? ${ }^{50}$

This chapter does not seek to answer such questions. Instead, this Part assumes arguendo that at least some contracting parties have a moral obligation to perform in order to ask how such obligations might figure into the explanatory reasons for the associated legal obligations. The next Part discusses several theories that make no such assumptions about parties' moral obligations.

Parties' moral obligations might figure into the explanation of their contractual ones in any of four ways: contract law might be designed enforce the first-order moral obligation to perform; it might enforce, or empower parties to enforce, ${ }^{51}$ second-order remedial duties generated by the breach of their first-order obligations; it might seek to provide support to the social moral practice of making and keeping agreements; or it might be structured at least to avoid interfering with parties' moral lives or doing harm to the moral practice..$^{52}$ The first two types of explanation posit that contract law enforces parties' moral obligations, first- or second-order. The second two focus on the law's effects on moral culture and agency.

Least plausible is the claim that contract law is designed only to enforce parties' first-order moral obligations to perform. Liam Murphy identifies the two reasons for doubt..$^{53}$ First, contract remedies seem designed not to punish or deter breach, but to compensate the nonbreaching party for harms caused by breach. Murphy argues that if the goal were to enforce performance, the presumptive remedy would be at least specific performance. My own view is

${ }^{49}$ See Curtis Bridgeman, The Morality of Jingle Mail: Moral Myths about Strategic Default, 46 WAKE ForeST L. REV. 123 (2011); Tess Wilkinson Ryan, Breaching the Mortgage Contract: The Behavioral Economics of Strategic Default, 64 VAND. L. REV. 1547 (2011).

${ }^{50}$ See Alan Schwartz \& Robert E. Scott, Contract Theory and the Limits of Contract Law, 113 YALE L.J. 541, 556 (2003) (suggesting that artificial persons are subject only to the morality required by positive law).

${ }^{51}$ The possible application of recourse theories to the law of contracts deserves more than the above nod but would require a significant detour. See John Goldberg \& Benjamin Zipursky, Torts as Wrongs, 88 TEX. L. REV. 917 (2010) (describing the civil recourse theory); Nathan B. Oman, Consent to Retaliation: A Civil Recourse Theory of Contractual Liability, 96 IoWA L. REV. 529 (2011) (seeking to marry civil recourse theory with a consent theory).

${ }^{52}$ For variations on this list, see Liam Murphy The Practice of Promise and Contract, in Philosophical Foundations of Contract LaW 151 (G. Klass et al. eds., Oxford Univ. Press 2014); Klass, supra note 29, at 707-09.

${ }^{53}$ Murphy, supra note 52, at 156-58. Although Murphy focuses on Fried's promise theory, his points apply equally to the idea that contract law might enforce nonpromissory agreement-based moral obligations. 
that not even specific performance would be enough. Specific performance does not enforce the duty to perform, as it does not ensure that the nonbreaching party gets what she bargained for: the other side's willing performance. Specific performance provides instead only a judicially mandated substitute for performance, secured through litigation. A contract law designed to enforce the moral obligation to perform would include punitive damages, disgorgement or other deterrence based remedies. ${ }^{54}$ Either way, however, the general point remains: remedies for breach do not appear to enforce performance obligations.

Second, enforcing the moral duty to perform violates the liberal commitment to maintaining the distinction between the right and the good. "For Millian liberals, who reject coercion merely for the sake of improving a person's own welfare, or enforcing their obligations, or making them more virtuous, the moralist view of contract law does not get off the ground." 55 Performance duties are not the sort of moral obligations a liberal society wants the law to enforce.

If contract law does not aim to enforce a first-order moral obligation to perform, it might seek to enforce second-order moral obligations generated by nonperformance. Theories of corrective justice come in many varieties, some more convincing than others. ${ }^{56}$ My own view is that a plausible account for a theory of contract law starts from Joseph Raz's "conformity principle," which John Gardner restates as follows:

When we have a primary obligation to $\phi$ at $t 1$, but do not to $\phi$ at $t 1$, we acquire, all else being equal, a secondary obligation to come as close as we now can to $\phi i n g$ at $t 1$, where closeness is determined by the reasons for the original obligation. This may involve nearly ping at $t 2$, or

${ }^{54}$ Although several theorists have recommended disgorgement for certain forms of breach, and the idea made it into the Third Restatement of Restitution and Unjust Enrichment, U.S. courts have not followed suit. See RESTATEMENT (THIRD) OF RESTITUTION AND UNJUST ENRICHMENT § 39 (2010); Andrew Kull, Restitution as a Remedy for Breach of Contract, 67 S. CAL. L. REV. 1465 (1994) (advocating disgorgement for some breaches); Hanoch Dagan, THE LAW AND ETHICS OF RESTITUTION 261-82 (2004) (examining the moral complexities of disgorgement for breach); Caprice L. Roberts, Restitutionary Disgorgement for Opportunistic Breach of Contract and Mitigation of Damages, 42 LOYOLA L. REV. 131, 134 (2008) (arguing that section 39 has little support in U.S. caselaw). ${ }^{55}$ Id. at 157.

${ }^{56}$ For discussions the application of corrective justice theories to contract law, see Murphy, id. at 158-62; Curtis Bridgeman, Note: Corrective Justice in Contract Law: Is There a Case for Punitive Damages?, 56 VAND. L. REV. 237 (2003). 
precisely ping at $t 3$, or (eventually) doing something at $t 27$ that has something in common with $\phi i n g .{ }^{57}$

In short, "the secondary obligation is a rational echo of the primary obligation, for it exists to serve, so far as may still be done, the reasons for the primary obligation that was not performed when its performance was due." ${ }^{58}$ If the reasons for a party's first-order moral obligation to perform a contractual agreement include, for example, an uncompensated benefit conferred on her by the other party or the other party's detrimental reliance on the agreement, those reasons survive nonperformance and arguably generate a second-order moral duty to compensate.

There is an argument that such remedial moral obligations cannot explain contract remedies. Contract law enforces executory agreements, which have not yet been relied on or performed by either side. And recovery often takes the form of expectation damages, which as Lon Fuller observes, claim to "'compensate' the plaintiff by giving him something he never had" - the benefit of performance. ${ }^{59}$ These remedial rules might be thought to belie the idea that contract remedies enforce second-order duties that derive from benefits received or detrimental reliance. Alternatively, some theorists address this worry with arguments that contract is better understood instead as the transfer of an entitlement or the creation of a right to performance. ${ }^{60}$

My view is that such metaphysical moves are unnecessary. ${ }^{61}$ As Fuller observes, one often finds a divergence between the "measure" of damages and the "motive" for imposing them. Fuller identifies two reasons. First, an area of

${ }^{57}$ John Gardner, What Is Tort Law For? Part 1. The Place of Corrective Justice, 30 LAW AND PHILOSOPHY 1, 38 (2011).

${ }^{58}$ Id. at 40. Raz's formulation is: "One should conform to reason completely, insofar as one can. If one cannot, one should come as close to complete conformity as possible." Joseph Raz, Personal Practical Conflicts, in PRACTICAL Conflicts: NeW PhILOSOPHICAL EsSAYS 172, 189 (Peter Baumann \& Monika Betzler eds., Cambridge U. Press 2004).

${ }^{59}$ L.L. Fuller and William R. Perdue, Jr., The Reliance Interest in Contract Damages: 1, 46 YALE L.J. 52, 53 (1936).

${ }^{60}$ See, e.g., Andrew S. Gold, A Property Theory of Contract, 103 NW. U. L. REV. 1 (2009); Peter Benson, Contract as a Transfer of Ownership, 48 WM. \& MARY L. REV. 1673 (2007); Ernst Weinrib, Punishment and Disgorgement as Contract Remedies, 78 CHI.-KeNT L. ReV. 55 (2003). Alternatively, P.S. Atiyah simply suggested we "dethrone the executory contract from the central place which it occupies in Contract theory." P.S. Atiyay, Contracts, Promises and the Law of Obligations, 94 L.Q. REV. 193, 220 (1978).

${ }^{61}$ David Owens argues that transfer theories also mischaracterize promissory obligations. David Owens, Does a Promise Transfer a Right, in PHILOSOPHICAL Foundations of Contract LaW 78 (G. Klass et al. eds., Oxford Univ. Press 2014). 
law might serve multiple functions or be justified by multiple principles. ${ }^{62}$ If the law has "mixed motives," the remedy might not perfectly match each function or justification, or even the primary ones. Second, practical considerations such as difficulties in proof or measurement often recommend an alternative remedy. "[E]ven where it is reasonable to suppose that a single interest furnishes the exclusive raison d'être of legal intervention it is still possible for reasons of convenience and certainty the court may choose a measure of recovery which differs from that suggested by the interested protected." ${ }^{\prime 63}$ Remedies for breach might serve to enforce second-order moral obligations without perfectly tracking the reasons for those obligations.

The above discussion has not yet made a complete case for a corrective justice theory of contract law. That case would, among other things, need to explain why if the law does not strictly enforce the first-order moral obligation to perform, it should enforce the second-order moral obligations that result from breach. Here Mill's harm principle might be of some use. Be that as it may, corrective justice accounts at least perform better on the dimension of fit. Contract remedies appear designed not so much to punish or deter breach as to compensate the nonbreaching party for the harms breach causes.

A third variety of moral explanation emphasizes law's broader social functions. Several scholars have suggested that contract law is designed not (or not only) to enforce parties' moral obligations, but instead (or in addition) to support the social practice of entering into and keeping morally binding agreements. Raz, for example, argues that Mill's harm principle casts doubt on "the legitimacy of the law's adoption of a general principle of enforcing voluntary obligations," but "does not preclude the law from encouraging moral, cultural or other valid goals." ${ }^{64}$ Along the same lines, Shiffrin suggests that contract law "is not an effort to legalize as much as possible the interpersonal moral regime of promising, but rather to provide support for the political and public values associated with promising." ${ }^{65}$

The function that these social-effects accounts attribute to contract law relies on an empirical claim: that by recognizing and enforcing agreement-based moral obligations, the law strengthens moral culture. The interaction between moral culture and legal enforcement, however, is complex. Dori Kimel, for example, has hypothesized that "enforceability casts a thick and allencompassing veil over the motives and the attitudes towards each other... leaving reliance, performance, and other aspects of contractual conduct largely

${ }^{62}$ Fuller \& Perdue, supra note 59, at 66 ("[I]t is impossible to assume that when a court enforces a promise it necessarily pursues only one purpose and protects only one 'interest'.").

${ }^{63}$ Id. at 66-67.

${ }^{64}$ Joseph Raz, Promises in Morality and Law, 95 HARV. L. ReV. 916, 937 (reviewing P.S. Atiyah, PROMISES, MORALS, AND LAW (1981)).

${ }^{65}$ Seana Valentine Shiffrin, The Divergence of Contract and Promise, 120 HARV. L. REv. 708, 752 (2007). See also Murphy, supra note 52, at 168-70. 
devoid of expressive content." ${ }^{66}$ Or consider the famous Israeli day-care experiment in which imposing a late-pickup fine on parents apparently undermined a social norm of picking children up on time, rather than reenforcing it. ${ }^{67}$ None of this is to say that legal enforcement cannot be used to support moral practices. (I am skeptical, for example, of Kimel's veil hypothesis.) But the question of when and how it does so cannot be answered in the abstract, and is likely to be highly context dependent. ${ }^{68}$

The same goes for a fourth possible moral explanation. Whether or not contract law supports the social practice of making and keeping agreements, we should at least want it not to undermine that practice. At a minimum contract law should, in Shiffrin's words, "be made compatible with the conditions for moral agency to flourish." ${ }^{69}$

This do-no-harm principle is attractive. But its application again involves difficult empirical judgments. Shiffrin, for example, argues that by refusing to order specific performance and declining to award unforeseeable damages, contract law "fails to use its distinctive powers and modes of expression to mark the judgment that breach is impermissible as opposed to merely subject to a price." ${ }^{70}$ But are we certain about those rules' expressive content and practical effects? By awarding the expected value of performance, the law might be understood to recognize the moral duty to perform while declining to enforce it. And the foreseeability rule might be read to reflect each party's obligation, at the time of formation, to share information about the costs of nonperformance. ${ }^{71}$ Claims about the deleterious effects of individual contract doctrines on moral culture or agency are no less empirical than those concerning support for those practices, and resist armchair answers for the same reasons.

${ }^{66}$ Dori Kimel, From Promise to Contract 74 (2005). See also Aditi Bagchi, Separating Contract and Promise, 38 FL. ST. U. L. REV. 707 (2011) (arguing that legal enforcement of private, morally binding promises interferes and undermines the moral sphere).

${ }^{67}$ Uri Gneezy \& Aldo Rustichini, A Fine Is a Price, J. LEGAL STUd. 1 (2000).

${ }^{68}$ For a start in thinking about empirically assessing whether contract enforcement supports the moral practice, see Tess Wilkinson-Ryan, Legal Promise and Psychological Contract, 47 WAKE FOREST L. REV. 843 (2012). For more on the complex interaction between legal enforcement and extralegal norms and behavior, see, e.g., Daphna Lewinsohn-Zamir, The Choice Between Property Rules and Liability Rules Revisited: Critical Observations from Behavioral Studies, 80 TEX. L. REV. 219 (2001).

${ }^{69}$ Shiffrin, supra note 65 , at 712.

${ }^{70} / d$. at 724.

${ }^{71}$ George Letsas and Prince Saprai have similarly argued that the mitigation rule has a moral meaning different from the one Shiffrin assigns it. George Letsas \& Prince Saprai Mitigation, Fairness, and Contract Law, in PHILOSOPHICAL Foundations of CONTRACt LAW 319 (G. Klass et al. eds., Oxford Univ. Press 2014). 
Before leaving moral explanatory theories, I want to return to the various senses in which contractual obligations might be said to be voluntary. I have argued that contracting parties' moral obligations are often only first or second grade voluntary. None of the above theories presupposes that parties' legal obligations are voluntary in a more demanding sense. They do not presuppose that contracting is a legal normative power, that the law seeks to ensure that parties intend the contractual obligations they acquire. None of the above functions contract law might serve-enforcing the parties' first- or second-order moral obligations, supporting the moral practice, or doing no harm to that practice-assumes parties' intent to contract, though all are compatible with parties sometimes or even always intending to be legally bound. Moral explanatory theories therefore allow that contractual obligations might be first, second or third grade voluntary.

\section{Separate Spheres and the Similarity of Promise and Contract}

Several theoretical approaches reject the idea that the parties' contractual obligations are explained by their moral ones, but view contracting as something like the legal analog of promising. Entering into a contract, according to these theories, is the exercise of a legal normative power, in the same way making a promise is the exercise of a moral normative one. I begin with two arguments that entering into a contract is always the exercise of a normative power-that contract law is, or should be, designed to sort for the parties' intent to be legally bound. I then consider the more modest claim that contracting is sometimes the exercise of a normative power-that the parties' apparent intent to be legally bound might be a sufficient reason for enforcement without being a necessary one.

\subsection{Contract Law as Pure Power-Conferring Rule}

Randy Barnett advances a strong version of the claim that contracting is a normative power. Rather than looking to the moral sphere, Barnett seeks to ground contract law a neo-Lockean theory of legal entitlements. ${ }^{72}$ That theory begins with a commitment to promoting individuals' ability to pursue and achieve happiness, peace, and prosperity. In a world of scarce resources, those individual pursuits can come into conflict. Legal entitlements mediate such conflicts. "A theory of entitlements specifies the rights that individuals possess

${ }^{72}$ A detailed version of the theory can be found in Randy E. Barnett, THE StRUCTURE OF LIBERTY: JUSTICE AND THE RULE OF LAW (Oxford: Clarendon Press, 1998). Barnett expressly rejects any explanatory connection between parties' moral and legal obligations. To enforce the moral obligation would be "tantamount to enforcing virtue," confusing the good with the right. Randy E. Barnett, Contract Is Not Promise; Contract is Consent, in PHILOSOPHICAL Foundations of CONTRACT LAW 42, 47 (G. Klass et al. eds., Oxford Univ. Press 2014). 
or may possess; it tells us what may be owned and who owns it; it circumscribes the individual boundaries of human freedom."73 The commitment to individual choice further recommends permitting persons to transfer their legal entitlements when they wish-for example, by entering into a contract that gives the other side a legal entitlement to one's future performance.

Barnett's autonomy theory understands entering into a contract as the exercise of a legal power.

In a system of entitlements where manifested rights transfers are what justify the legal enforcement of agreements, any such manifestation necessarily implies that one intends to be "legally bound," to adhere to one's commitment. Therefore, the phrase "a manifestation of an intention to be legally bound" neatly captures what a court should seek to find before holding that a contractual obligation has been created. ${ }^{74}$

Barnett's consent theory recommends the English rule: contract liability should attach when and only when the parties intend that their agreement be enforceable. In U.S. jurisdictions, where that rule is not part of the black-letter law, other doctrines and tacit judicial judgments can in practice sort for the parties intent to contract. ${ }^{75}$ Although Barnett does not put it this way, contract emerges as the legal analog to promise. Just as promising gives individuals the power to undertake new moral obligations when they wish, so contract law gives parties the power to undertake new legal ones.

Economic analyses of contract law start from a very different place, but commonly arrive at a similar picture of contracting. Economic theorists typically model contractual exchanges as transactions between self-interested rational utility maximizers. Most further assume that parties are insensitive to any moral obligations that attached to their exchange agreements, but highly attuned to the legal consequences of nonperformance. ${ }^{76}$ Rational choice theory and

${ }^{73}$ Randy E. Barnett, A Consent Theory of Contract, 86 CoLUM. L. REV. 269, 291 (1986). See generally id. at 290-300. For a recent restatement, see Randy E. Barnett, Contract Is Not Promise; Contract is Consent, in PHILOSOPHICAL Foundations of Contract LaW 42 (G. Klass et al. eds., Oxford Univ. Press 2014). ${ }^{74}$ Id. at 304 (footnotes omitted).

${ }^{75}$ See id. at 313 (arguing that consideration sorts for intent to contract); Barnett \& Becker, supra note $16,449-85$ (arguing that in most cases in which courts apply the doctrine of promissory estoppel, the parties intended legal liability). ${ }^{76}$ For an example of a model that drops the first assumption but keeps the second, see Jody S. Kraus \& Robert E. Scott, Contract Design and the Structure of Contractual Intent, 84 N.Y.U. L. REV. 1023, 2029-31 (2009). For general thoughts on expanding economic models to take account of parties' moral obligations and motivations, see Rebecca Stone, Legal Design for the "Good Man", 102 VA. L. REV. 1767 (2016); Eyal Zamir \& Barak Medina, Law, Morality, and Economics: 
microeconomic analysis are then applied to determine the incentive effects of various legal rules. Early economic analyses of contract law focused on the legal incentives to perform, arguing that in the model, expectation damages incentivize performance when and only when performance is efficient. ${ }^{77}$ Later analyses paid more attention to the legal incentives on both parties across the life of the transaction-from investing in the possible deal before formation to post-breach behavior. ${ }^{78}$

Practitioners of economic analysis have not paid much attention to whether the law should condition enforcement on parties' contractual intent. The reason might be that economic theories of law are more common in the United States, where the doctrinal question is not especially salient. Or it might be because the answer is so obvious given the approach's methodological commitments, which suggest at least three reasons to think that the law does or should condition contractual liability on the parties' intent to contract.

First, the assumption that parties are highly attuned to legal consequences entails that parties know when they are entering into a legally binding contract. To the extent that parties are able avoid legal liability when they wish-by specifying that their agreement shall not be legally enforceablethe model suggests that parties who do not opt-out of enforcement must want it. $^{79}$

Second, in the model parties often want legal enforcement. The assumptions of party self-interest and insensitivity to moral obligations entail that, absent legal enforcement, parties might not trust in one another's future performance. ${ }^{80}$ Reputation and repeat play sometimes suffice. But in the model, there is often a Hobbesian problem: "he that performeth first has no assurance that the other will perform after, because the bonds of words are too weak to brindle men's ambition, avarice, anger, and other passions, without the fear of

Integrating Moral Constraints within Economic Analysis of Law, 96 CAL. L. REV. 323 (2008).

77 See Gregory Klass, Efficient Breach, in PHILOSOPHICAL Foundations of CONTRACT LAW 362 (G. Klass, et al. eds., Oxford Univ. Press 2014).

${ }^{78}$ See Richard Craswell, Two Economic Theories of Enforcing Promises, in THE THEORY OF CONTRACt LAW: NeW EsSAYS 19 (P. Benson ed., Cambridge U. Press 2001).

${ }^{79}$ See id. at 42-43 (suggesting that enforcement of contractual agreements is a majoritarian default and therefore compatible with a requirement that the parties intend legal liability); Richard Craswell, Offer, Acceptance, and Efficient Reliance, 48 StAN. L. REV. 481 (1996) (using economic analysis to determine when parties are likely to want enforcement, and using the results to identify majoritarian defaults).

${ }^{80}$ Many but not all. Reputation and repeat play can also provide reasons to perform. 
some coercive power." ${ }^{11}$ Legal enforcement solves this mistrust problem by both deterring many breaches and insuring the nonbreaching party against those that occur. Because parties stand to benefit from value-creating exchanges, both therefore often want legal enforcement of their exchange agreements.

Third, many economic theorists incorporate into their analyses a further assumption: that parties know what is in their individual self-interest better than do lawmakers or courts. That premise suggests giving parties the power to determine when and how their agreements should be enforced. Lisa Bernstein, for example, writes that "[i]n structuring their contracting relationship, transactors allocate aspects of their relationship between the legal and extralegal realms in ways that seek to maximize the value of their transaction." 82 The rules of contract interpretation and enforcement, in turn, should be structured to maximize parties' ability to choose the legal obligations they wish. ${ }^{83}$

This point brings us full-circle back to autonomy theories. Charles Fried has recently observed a convergence between autonomy theories and economic analysis, which he attributes to their shared commitment to the proposition that "the law should be designed to allow people in voluntary relationship to structure their relationship in the way that they judge will best serve their interests over the long run, at least insofar as they may be deemed the best judges of their own interests." ${ }^{84}$ The upshot is that, like Barnett's autonomy theory, economic analyses picture contract as legal normative power. Contractual obligations are third grade voluntary-not incurred, but undertaken.

Neither autonomy nor economic theories ground parties' contractual obligations in their moral ones. Neither treat contracts as promises. But both understand contracts as similar to promises. Entering into a contract is the intentional undertaking of a new legal obligation, just as promising is the intentional undertaking of a moral one. Contracting is the exercise of a legal normative power in the same way promising is the exercise of a moral normative power.

81 Thomas Hobbes, LeVIATHAN 84 (E. Curly ed., Hackett 1994) (1651). Richard Posner opens his analysis of contract by describing a version of Hobbes's mistrust problem. Richard Posner, ECONOMIC ANALYSIS OF LAW 93 (6th ed., Aspen 2003).

${ }^{82}$ Lisa Bernstein, Merchant Law in a Merchant Court: Rethinking the Codes Search for Immanent Business Norms, 144 U. PA. L. REV. 1765, 1788 (1996).

${ }^{83}$ Bernstein argues, for example, that the Uniform Commercial Code's rules regarding course of performance and course of dealings reduce parties' ability to get the legal terms they want. Id. at 1804.

${ }^{84}$ Charles Fried, The Ambitions of Contract as Promise, in PHILOSOPHICAL Foundations of CONTRACT LAW 17, 22 (G. Klass, et al. eds., Oxford Univ. Press 2014). 


\subsection{Contract Law as a Partial Power-Conferring Rule}

Both Barnett's consent theory and economic models suggest that the parties' intent to be legally bound should, to the extent practicable, be a necessary condition of contractual liability. One need not be committed to either theory, however, to recognize that giving parties the legal power to undertake contractual obligations when they wish expands their autonomy, and that this is a good thing. No matter how common Hobbes's mistrust problem, there is no doubt that contract law sometimes allows parties to enter into joint projects that would otherwise fail for a lack of trust. As Hanoch Dagan and Michael Heller observe, contract law "empowers individuals ... to make agreements that facilitate their ability legitimately to enlist one another in pursuing private goals and purposes - and thus contract law enhances our ability to be the authors of our own lives." ${ }^{85}$ Contract law does this by giving parties the ability to undertake new legal obligations when they wish.

Such an autonomy-enhancing function of contract law presumes that parties sometimes intend legal liability and that this is a sufficient reason to provide it. It does not, however, presuppose that parties always intend to contract - that evidence of the parties' intent to contract should be a necessary condition of contractual liability. In short, the positive freedom to enter a contract when one wishes does not presuppose a negative freedom from unintended contracts.

\section{The Plural Functions of Contract Law}

All of the theories discussed in this article are broadly speaking interpretive ones. Each seeks to identify the functions and justifications that best explain the law of contract we find in the world around us. One group locates the explanation in the parties' agreement-based moral obligations. Contract law might function to enforce parties' first-order moral obligations to perform, to enforce the second-order remedial obligations that attach to breach, to support the moral practice and culture of making and keeping agreements, or to at least do no harm to that practice and culture. Another group explains the law of contract without recourse to the parties' moral obligations, but pictures contract as the legal analog to promise. Rather than pointing to parties' moral obligations, these theories emphasize ways that contract law expands individual autonomy and adds to welfare. Although they do not posit an explanatory connection between contract and the moral sphere, they tend to view contract as a legal normative power that is very much like the moral normative power of promising.

There is a strong tendency among contract theorists to adopt one or another of the above two approaches-one or the other of these pictures of contract. But there is no inconsistency between them. Contract law might

${ }^{85}$ Hanoch Dagan \& Michael Heller, THE CHOICE THEORY OF CONTRACTS 41 (2017). 
function to enforce parties' agreement-based moral obligations and support moral culture generally and at the same time, by enabling parties to intentionally enter into legally binding agreements, serve to extend their ability to engage in joint projects.

In previous work I have called this the "compound theory" of contract. ${ }^{86}$ Whereas most laws can be classified as either duty-imposing or powerconferring, contract law appears to be both at once. It both imposes on parties to exchange agreements a legal obligation to perform for reasons independent of the parties' probable contractual intent, and confers on them the power to undertake that legal obligation when they so intend because they so intend. The law is structured to make room for contractual obligations that are first grade voluntary and at the same time recognizes and enables third grade voluntary contractual obligations.

The compound theory is a form of pluralism: it understands contract law as a multi-purpose tool. ${ }^{87}$ But it is a structured pluralism. The individual functions contract law serves give it a distinctive dual structure. Contract law both imposes duties on parties to exchange agreements and gives those parties the power to undertake new legal obligations and restructure their existing ones. I have argued elsewhere that the compound theory provides the best interpretation of the rules of contract formation and construction we find in the world around us, especially those that govern formation. Here I merely note that a compound theory also accounts for an aspect of contract law that simple theories tend to obscure.

Whereas simple moral theories tend to view contract law as responding to parties' exogenously given moral obligations, a compound theory suggests that the law might also serve to identify and structure them. The point here is akin to Hart's observation that the law seeks not only to deter the Holmesian bad man (an idea that reappears in economic accounts), but also to give guidance to the puzzled one. ${ }^{88}$ Lawmakers can and do set defaults and mandatory rules to take account of shared social understandings of what parties owe one another. These can range from the morally thin obligations between, say, traders in the derivatives market to much thicker obligations, such as those between employers and employees or landlords and tenants. By the same token, parties who know they are entering into a legally binding agreement can look to legal default and mandatory terms for information about not only their

${ }^{86}$ Gregory Klass, Three Pictures of Contract: Duty, Power and Compound Rule, 83 N.Y.U. L. REV. 1726 (2008). Peter Benson has recently advanced a somewhat different version of a compound theory. Peter Benson, Unity and Multiplicity in Contract Law: From General Principles to Transaction Types, 20 THEOR. INQ. L. 537 (2019). See also Curtis Bridgeman \& John C.P. Goldberg, Do Promises Distinguish Contract from Tort?, 45 SUFFOLK. U. L. REV. 873, 876-79 (2012).

${ }^{87}$ See Roy Kreitner, On the New Pluralism in Contract Theory, 45 SUfFolk U. L. REV. 915 (2012).

${ }^{88}$ H.L.A. Hart, The CONCEPT OF LAW 40 (2d ed. Oxford Univ. Press 1994). 
legal obligations, but also their moral ones. The compound theory explains how it is that contract law can in this way both respond to and structure parties' moral relationships. Contractual obligations can be both first- and third-grade voluntary, and contract law can be one and the same time both a duty-imposing and a power-conferring rule. 